\title{
KONSEP WARALABA PERSPEKTIF EKONOMI ISLAM
}

\author{
Inas Fahmiyah" ${ }^{1}$, Moh. Idil Ghufron ${ }^{2}$ \\ Universitas Nurul Jadid \\ Fahmiyahinas@gmail.com ${ }^{1}$, aidil.piero7@gmail.com²
}

\begin{abstract}
Abstrak : Perkembangan dunia industri semakin pesat, beraneka ragam usaha di buka dengan leluasa. Ada banyak kopsep yang digunakan dalam berbisnis, salah satunya ialah konsep waralaba. Konsep ini adalah salah satu model bisnis termudah dan telah terbukti keberhasilannya dalam dunia bisnis. Tulisan ini dilatarbelakangi oleh pesatnya pertumbuhan bisnis sistem waralaba di Negeri kita Indonesia. Permasalahan yang akan dikaji adalah bagaimana perkembangan bisnis waralaba di Indonesia dan bagaimana perspektif ekonomi Islam tentang bisnis waralaba tersebut. Dalam Islam, sistem waralaba dikenal dengan nama syirkah yakni perserikatan antara dua orang atau lebih dan keuntungan dibagi sesuai kesepakatan bersama. Sistem bagi hasil adalah sistem pembagian keuntungannya menurut konsep syariah Ekonomi Islam.
\end{abstract}

\section{Kata kunci: Bisnis, Waralaba, dan Ekonomi Islam}

Abstract : The development of industrial world is increasingly rapid, various businesses are opened freely. There many concept used in business, one of them is franchise concept. This concept is one of kind bussines easely and most successful business models. This article is motivated by the rapid growth of the franchise business in our country Indonesia. The problems that will be examined are the development of the franchise business and how the Islamic economy views the franchise business. In Islam a franchise system is known as syirkah, namely a union between two or more people and profits are divided according to mutual agreement. The profit sharing is a profit system according to the sharia concept.

\section{Keywords: Business, Franchise, and Islamic Economic}

\section{PENDAHULUAN}

Salah satu penghasil keuntungan ialah bisnis atau perdagangan. Dalam hal ini masyarakat mengambil keuntungan melalui barang yang dijualnya melebihi harga beli yang diterima. Berbisnis merupakan suatu kesejahteraan hidup masyarakat karena pendapatan yang diterimanya adalah nilai maksimum bagi produsen. Bisnis atau berdagang merupakan salah satu kegiatan masyarakat dalam memenuhi kebutuhan hidup keluarga. Berbisnis juga turut membangun kegiatan ekonomi rumah tangga sekaligus ekonomi Indonesia pada umumnya. Berbisnis juga dapat mengurangi pengangguran yang ada. Bisnis adalah pekerjaan yang dianjurkan Rasulullah dalam mencari pendapatan maksimum. Motivasi utama dari kegiatan bisnis adalah

Received: 2019-01-02| Reviced: 2019-02-14| Accepted: 2019-02-14

Indexed : DOAJ, Garuda, Crossref, Google Scholar | DOI : https://doi.org/10.29313/amwaluna.v3i1.4287 
laba (perbedaan antara peghasilan dan biaya yang dikeluarkan). Harus terdapat kejelian dalam mengambil laba.

Pertumbuhan dan pembangunanekonomi menjadi perhatian di setiap negara di seluruh dunia. Hal ini dikarenakan bisa menjadi tolak ukur dari perkembangan negara dari tahun ke tahun. Bisnis juga berguna untuk menaikkan pendapatan nasioanal riil sekaligus produktivitas.

Bagi negara berkembang pembangunan ekonomi bertujuan meningkatkan taraf hidup masyarakat. Indonesia bukan negara maju melainkan negara berkembang. Oleh karenanya inovasi-inovasi harus terus dilakukan dan dikembangkan salah satunya inovasi dalam hal ekonomi. Pesatnya pertumbuhan ekonomi adalah berkembangnya sistem pemasaran dalam berbagai bidang usaha, seperti Waralaba (franchise), Perniagaan Secara Elektronik (Electronic Commerce), Electronic Fund Transfer (EFT), Kartu Kredit (Credit Card), dan lain-lain. Hakikatnya kegiatan usaha bisnis bebas dilaksanakan sepanjang kegiatan usaha tersebut tidak bertolak belakang dengan perundang-undangan.

Persaingan perdagangan di era distruptive saat ini semakin ketat dan memerlukan sistem pemasaran yang mendukung dan harus menghadapi beberapa macam tantangan dan resiko yang ada serta bisa mengatur strategi jitu untuk selalu berhasil dalam berbisnis. Sekaligus harus jeli dalam menghadapi pasar global. untuk pemasaran tinggi juga memerlukan biaya tinggi pula sehingga timbul alternatif bagi para pengusaha untuk menghemat biaya dengan melakukan pemasaran melalui bisnis sistem waralaba. salah satu cara yang efektif dan efisien karena sistem ini tidak mengeluarkan banyak modal dalam memiliki usaha sendiri meski tidak sempurna menjadi hak milik mereka. Dan berhasil menarik minat masyarakat untuk melakukannya. Terbukti usaha yang diwaralabakan adalah usaha-usaha yang telah teruji dan sukses di bidangnya, sehingga anggapan masyarakat dapat mendatangkan keuntungan, faktor ini yang kemudian menjadi daya tarik animo masyarakat secara luas.

Waralaba memiliki konsep yang sudah teratur. Tidak diperlukan memulai usaha dari nol, karena terdapat sistem terpadu dalam waralaba, yang memungkinkan seorang penerima waralaba menjalankan usaha dengan baik. Hal ini menunjukkan semakin tinggi daya saing antar industri pedagangan dalam melakukan pemasaran juga industri barang atau jasa. 
Terdapat perjanjian dalam sistem waralaba yang harus disepakati dari awal. Suatu perjanjian mengenai metode pendistribusian barang atau jasa kepada konsumen.

Bisnis dengan sitem waralaba merupakan suatu aktifitas usaha dari pengusaha kecil yang ada di Indonesia agar dapat berkembang secara wajar dengan menggunakan resep, teknologi, kemasan, manejemen pelayanan, merek dagang, atau jasa pihak lain dengan membayar sejumlah royalty berdasarkan lisensi waralaba. Cukup dengan menyediakan modal kemitraan usaha franchise telah mendapatkan pelatihan keterampilan usaha dari pihak franchisor dan mendapatkan hak usaha yang sama dengan franchisor.

Sistem franchise sebagai model pengembangan kemitraan bisnis telah terbukti keberadaannya dalam perekonomian nasional karena telah menawarkan peluang sangat besar kepada calon wirausahawan untuk memilki dan mengembangkan usahanya dengan rasio keberhasilan yang tinggi. Dengan berkembangnya bisnis sistem waralaba di indonesia saat ini akan memicu pertumbuhan ekonomi Indonesia pula. Hal ini turut membantu perekonomian di
Indonesia dalam persaingan global. Faktanya sangat banyak bisnis franchise disekitar kita saat ini diantaranya adalah Wandy's, Pizza Hut, McDonald's, KFC, franchise asing sedangkan franchise lokal terdapat Es Teler77, Alfamart, Indomart, Bakso Cak Eko, dll.

Contoh waralaba yang saling bersaing dan berlomba-lomba ialah Indomaret dan Alfamart, bahkan keduanya saling bersaing dan menjadi polemik yang berkepanjanganb ahkan ikut mempengaruhi pasar tradisional maupun (Pedagang Kaki Lima) PKL dan pedagang warungan. dimana sampai saat ini kajian tentang hal itu sampai pada tataran filosofis, idiologis, yuridis dan social budaya. (Rivai, 2012).

Hal ini menandakan sistem waralaba telah terbukti pencapaiannya terhadap peningkatan ekonomi di Indonesia. Kepercayaan timbul juga bagi para calon pengusaha untuk menirunya dengan tanpa inovasi sendiri hanya dengan mewaralaba bisnis tersebut dengan syarat membayar sejumlah royalty. Dan megikuti beberapa perjanjian yang ada. Bisnis dengan sistem waralaba ini telah menjadi tren dalam dunia investasi dan selalu berkembang disetiap tahunnya. 
Perlu penekanan sistem waralaba tidaklah bertentangan dengan ekonomi islam pada umumnya. Di dalamnya terdapat adanya kemitraan usaha dan kesepakatan antara kedua belah pihak. Islampun mengajarkan selalu untuk bermitra dalam menjalankan bisnis. Agar tidak hanya mendapat keuntungan materi saja. Nabi Muhammad telah malakukannya dengan sayyidah Khodijah (yang kemudian menjadi istri beliau) Dengan menjual barang dagangan milik Sayyidah Khodijah kemudian Nabi Muhammad memperoleh upah atas apa yang dikerjakan.

Kejujuran yang dimilkiNya membuat Nabi Muhammad menjadi Pengusaha sukses yang diperoleh dari bermitra Sayyidah Khodijah. Dalam islam terkenal dengan sebutan syirkah yakni perserikatan antara kedua belah pihak dan keuntungan dibagi sesuai kesepakatan bersama. Jadi berbisnis sistem waralaba dalam islam tidaklah sistem baru. Terpenting bagi seorang muslim ialah harus mengedepankan kemaslahatan umat dalam hal muamalah.

\section{PEMBAHASAN}

\section{Pengertian Bisnis Waralaba}

Bisnis adalah suatu kegiatan yang bersifat mencari keuntungan atau kegiatan komersil atau kegiatan yang mengeluarkan modal tertentu untuk memperoleh laba didefinisikan sebagai bisnis. (Hadi. 2011).

Kata bisnis berasal dari kata business, dari kata dasar busy yang berarti "sibuk", dalam hal individu ataupun komunitas. Dalam artian, sibuk mengerjakan aktivitas dan pekerjaan yang mendatangkan keuntungan. Jadi, Mencari laba adalah titik fokus dari berbisnis. Berbeda halnya dengan ekonomi yang lebih luas, bisnis lebih sempit hanya membahas tentang bagaimana cara memperoleh laba dalam suatu transasksi.

Tujuan bisnis atau usaha (dagang) ialah mendapatkan laba atau keuntungan yang merupakan cerminan pertumbuhan harta. Dari proses pemutaran modal dan pengoperasiannya dalam kegiatan dagang muncullah laba tersebut. Islam sangat mendorong penggunaan harta atau modal dan melarang menyimpannya hingga lupa dlam mengeluarkan zakat. Dan harta itu dapat merealisasikan perannya dalam aktivitas ekonomi. (Ghufron, 2017)

Sebelum waralaba mencuat di Indonesia, sistem bisnis ini telah terdapat di Eropa. Franchise adalah suatu hak khusus yang diberikan oleh suatu usaha 
manufaktur atau organisasi jasa franchise kepada pialang untuk menjual kembali dengan cara yang sama. Pengaturan seperti ini kadangkala disahkan dalam suatu perjanjian hak kelola yang merupakan kontrak antara pemilik hak kelola dan pemegang hak kelola. (Hadi, 2011).

Waralaba mulai dikenal di Indonesia pada tahun 1950-an disebabkan oleh munculnya dealer kendaraan bermotor melalui pembelian lisensi atau menjadi agen tunggal pemilik merk. Disamping produk local yakni perusahaan nasional Es teller 77 yang merupakan pelopor sistem pengoperasian dagangnya dengan sistem waralaba. Pada tahun 1991 telah memiliki 70 cabang baik di dalam negeri maupun luar negeri. (Rivai, 2012).

Kata waralaba adalah padanan kata dalam bahasa Indonesia untuk istilah franchise. Namun dalam praktiknya, istilah franchise justru dipopulerkan oleh Amerika Serikat. kata franchise dalam bahasa indonesia dapat disebut waralaba. Wara berarti lebih atau istimewa sedangkan laba berarti untung. Jadi waralaba ialah "lebih untung". intinya istimewa dalam berwirausaha dengan tanpa susah payah berinovasi terhadap merintis usaha baru. Cukup bermitra dengan Franchisor atau owner usaha tersebut dan membayar royalty sesuai kesepakatan. Dan franchise akan mendapat banyak keuntungan salah satunya ialah pelatihan keterampilan dalam usaha. istilah waralaba atau franchise bermula dari sejarah praktik bisnis di Eropa. (Rusli, 2015)

Sedangkan Menurut Charles L Vaughn, istilah franchise dipahami sebagai bentuk kegiatan pemasaran dan distribusi. Di dalamnya sebuah perusahaan memberikan hak atau kebebasan untuk menjalankan suatu usaha yang sama. Konsep dan hal terkait lainnya terdapat dalam sebuah perjanjian. Terhadap individu atau perusahaan yang relatif lebih kecil atau UKM. (Malik, 2007)

Asosiasi Franchise Indonesia (AFI) menyatakan bahwa waralaba ialah suatu sistem pendistribusian barang atau jasa kepada pelanggan akhir, dimana pemilik merek (franchisor) memberikan hak kepada individu atau perusahaan untuk melaksanakan bisnis dengan merek, nama, sistem, prosedur dan cara-cara yang telah ditetapkan sebelumnya dalam jangka waktu tertentu dan meliputi area tertentu. Sedangkan Peraturan Pemerintah Republik Indonesia Nomer 42/ Tahun 2007 tentang Waralaba menyatakan bahwa waralaba adalah perikatan dimana salah satu pihak 
diberikan hak memanfaatkan dan atau menggunakan hak dari kekayaan intelektual (HAKI) atau penemuan atau ciri khas usaha yang dimiliki pihak lain dengan suatu imbalan berdasarkan persyaratan yang ditetapkan oleh pihak lain tersebut dalam rangka penyediaan dan atau penjualan barang dan jasa. (Pidato pengukuhan guru besar dalam bidang ilmu manajemen, Sudarmiatin, dengan judul Praktik Bisnis Waralaba (franchise) di Indonesia, peluang Usaha dan Investasi).

Waralaba menurut konsultan waralaba Amir Karamoy adalah suatu pola kemitraan usaha antara perusahaan yang memiliki merek dagang dikenal dan sistem manajemen, keuangan dan pemasaran yang telah mantap, disebut pewaralaba, dengan perusahaan atau individu yang memanfaatkan atau menggunakan merek dan sistem milik pewaralaba, disebut terwaralaba. Pewaralaba wajib memberikan bantuan teknis, manajemen dan pemasaran kepada terwaralaba dan sebagai imbal baliknya, terwaralaba membayar sejumlah biaya (fees) kepada pewaralaba. Hubungan kemitraan usaha antara kedua pihak dikukuhkan dalam suatu perjanjian lisensi/waralaba. (Maratun Shalihah 2016)
Dari beberapa pengertian waralaba di atas dapat diringkas menjadi, suatu bentuk sistem bisnis kemitraan dengan bermodal kepercayaan atas apa yang akan franchise laksanakan dengan franchisor memberi keseluruhan konsep usahanya baik berupa merek dagangan resep yang dimilki maupun hak intelektual sekaligus pelatihan kewirausahaan terhadap franchise. dan sebagai franchise menerimanya dengan harus membayar royalty fee yang telah disepakati. Dan didalamnya terdapat sebuah perjanjian.

\section{Konsep Bisnis Waralaba}

Bisnis waralaba termasuk bisnis kemitraan, yakni bekerjasama dalam hal mencari keuntungan. Bermitra, perjanjian (KBBI) memiliki arti pesetujuan antara dua orang atau lebih baik secara tertulis maupun lisan. Akan tetapi perjanjian ini tidak mengikat salah satu melainkan sesuai kesepakatan bersama antar kedua belah pihak. Karena peraturan waralaba telah tertulis dalam peraturan pemerintah dan keduanya berhak mendapatkan perlindungan secara hukum. Keduanya wajib melaksanakan sesuai kesepakatan tersebut.

Perjanjian waralaba merupakan suatu tindakan hukum yang menimbulkan hak dan kewajiban bagi masing-masing pihak. 
Perjanjian waralaba franchisor memberikan hak kepada franchise sebagai mitra usahanya untuk menjalankan usaha dibidang yang sama dengan menggunakan merk dagang atau nama dagang dan hak milik intelektual lainnya serta menjaga standar kualitas dan reputasi franchisor sehubungan dengan penggunaan merk dari barang atau jasa yang telah diperjanjikan tersebut. (Puji Sulistyaningsih, 2017).

Franchise berhak menjalankan usaha dengan nama merek dagang dan segala bentuk manajemen teknis yang telah diterimanya dalam perjanjian tersebut sekaligus mendapat pembinaan khusus dalam bidang usaha dengan membeli keseluruhan terhadap franchisor yang disebut franchise fee (biaya pembelian hak franchise yang dikeluarkan olehnya setelaha dinyatakan memenuhi persyaratan sesuai kriteria franchisor). (Darmawan2008). Format dalam gambar tersebut jelas dan transparan atas apa yang akan dilakukan oleh kedua belah pihak. Menjadi tujuan keadilan bagi umat Islam. Hal ini tidak bertentangan dengan prinsip ekonomi Islam. (Maratun Shalihah 2016)

Perjanjian waralaba adalah bentuk perjanjian formal, karena perjanjian tesebut adalah termasuk dari syarat ketentuan undang-undang yang telah tertuang dalam Peraturan Pemerintah
Pemerintah Republik Indonesia nomer 42 tahun 2007 tentang waralaba. yang telah tertulis oleh mentri perdagangan. Perjanjian tersebut termasuk perjanjian kerjasama yang saling menguntungkan terhadap masing-masing pihak, dan mendapatkan perlindungan hukum. Perlu ditekankan waralaba akan terlaksana jika sebuah perusahaan yang di waralabakan telah termasuk dalam kriteria perusahaan jauh dari kata rugi.

Dalam bisnis franchise ini, yang dapat diminta dari franchisor oleh franchisee adalah sebagai berikut : Brand name (logo, merek, nama, aturan mengenai tampilan), System dan manual operasional bisnis, Dukungan dalam beroperasi. Karena Franchisor lebih mempunyai pengalaman luas serta sudah membina banyak Franchisees, sudah sepatutnya memiliki kemampuan untuk memberikan dukungan bagi Franchisee yang baru, serta Pengawasan (monitoring) Untuk memastikan bahwa sistem yang diberikan dijalankan dengan baik sesuai dengan prosedur dan benar secara konsisten. (Mayasari, 2017).

\section{Pengertian Ekonomi Islam}

Salah satu unsur penting (darury) bagi umat manusia ialah harta. Dengan harta kebutuhan manusia dapat terpenuhi dalam 
kehidupan. sekaligus dapat menunaikan kebutuhan ibadah dengan sempurna. Karena setiap sesuatu yang dibutuhkan oleh manusia harus melalui harta. Dalam artian membelanjakan harta untuk kemashlahatan hidup didunia demi mencapai tujuan ahirat. Serta dapat malaksanakan ibadah yakni ibadah mahdah (kita kepada Allah) atau ghoiru mahdah (sesama manusia). (Muhammad, 2004).

Arti ekonomi menurut bahasa ialah mengatur urusan rumah tangga. Para pakar ekonomi menyebutkan ekonomi ialah sebagai suatu usaha untuk mendapatkan harta demi mencapai tujuan hidup yakni dapat memenuhi kebutuhan hidup.(Idri, 2015)

Menurut Taqiyuddin Annabhani kata ekonomi bukan berarti kekayaan akan tetapi kegiatan yang mengatur urusan harta kekayaan. Baik didalamanya mencakup kegiatan memperbanyak jumlah kekayaan serta memperbanyak pengadaannya yang kemudian dibahas dalam ilmu ekonomi. (Linda 2015).

Dalam ajaran Islam, aktivitas ekonomi tidak dapat dilepaskan dalam ajaran-ajaran Alquran, hadist Nabi dan sumber lain (kesepakatan para ulama). Menurut S.M. Hasanuzzaman, ilmu
Ekonomi Islam adalah pengetahuan dan apliksi dari anjuran dan aturan syariah yang mencegah ketidakadilan dalam memperoleh sumber-sumber daya materil sehingga manusia puas dan tetap menjalankan perintah Allah serta mengikuti aturan masyarakat. Disisi lain Yusuf al-Qardhawi mendefinisikan ekonomi islam adlah ekonomi yang berdasarkan ketuhanan. Yakni bertujuan ahir kepada Allah, dan menggunakan sarana menurut syariat Allah.(Idri, 2015)

Kata ekonomi lebih luas mencakup tentang segala bentuk muamalah manusia dimuka bumi ini. Sedangkan islam sendiri ialah tunduk dan patuh atas apa yang diperintahkan oleh Allah. Dapat disimpulkan ekonomi islam merupakan kegiatan dalam mengurus harta kekayaan dengan berpedoman terhadap Amar makruf nahi mungkar yang Allah firmankan dalam Alquran.

Dalam bahasa Arab ekonomi Islam disebut dengan al-iqtishad al-Islami. Secara bahasa al-iqtishad berarti pertengahan dan berkeadilan (Maksud dalam pertengahan dan berkeadilan disini banyak ditemukan dalam Al-quran "dan sederhanalah kamu dalam berjalan. (Luqman: 19) dan "diantara mereka ada golongan yang pertengahan (Al-maidah: 
66). Maksudnya ialah orang yang berlaku jujur, lurus dan tidak menyimpang dari kebenaran. Juga didefinisikan sebagai pengetahuan tentang aturan yang berkaitan terhadap produksi kekayaan, mendistribusinya dan mengkonsumsi.

Dapat disimpulkan definisi ekonomi Islam adalah penerapan syariat dalam aktivitas ekonomi. Pentingnya ekonomi islam diterapkan disebabkan populasi umat muslim khususnya dinegara Indonesia yang semakin meningkat setiap tahunnya sesuai perkembangan laju ekonomi yang semakin pesat.

Ekonomi Islam memiliki beberapa prinsip diantaranya;

a. Allah menentukan benar atau salah Dalam hal ini terkait salah dan benar dalam hal ekonomi terdapat pada penentuan halal dan haram adalah hak progresif Allah.

b. Prinsip penggunaan

Prinsip penggunaan tidaklah membolehkan yang halal itu diulur terlalu jauh, sehingga menyebabkan terjadinya penggunaan yang berlebihan, serta memubadzirkan sumber-sumber ekonomi.

c. Prinsip pertengahan
Islam dengan tegas melarang umatnya melangkah melampaui batas hingga terjatuh kepada hal ekstrem. Kaum muslim disebut dalam Al-quran sebagai kaum pertengahan.

d. Kebebasan Ekonomi

Semua umat manusia akan diberi pertanggungjawaban atas apa yang telah dikerjakan selama ia berada di dunia penuh sandiwara ini. Allah telah memberi kebebasan dalam hal mencari harta, menikmatinya serta membelanjakannya. Ini juga terlihat kebebasan dalam hal memilih profesi, baik itu berbsinis maupun lainya.

e. Prinsip Keadilan Islam tidak membolehkan umatnya menumpuk harta melalui suap, korupsi,penggelapan, penipuan, dll. Karena hal ini akan merugikan salah satu pihak. Adil ialah sama rata, tidak berat sebelah.(Chudri 2012)

\section{Bisnis Waralaba ditinjau Dari Ekonomi Islam}

Waralaba ialah berbisnis dengan cara membeli HAKI untuk dipakainya. Berwirausaha dalam Islam sangatlah 
dianjurkan agar mandiri dengan segala kebutuhan hidupnya.

Sadono Sukirno menyatakan salah satu penyebab pengangguran ialah kekurangan pengeluaran agregat. Produksi barang atau jasa bagi para pengusaha hanya bertujuan menghasilkan keuntungan. Keuntungan tersebut hanya akan didapat jika para pengusaha dapat menjual barang yang telah diproduksi. Semakin banyak permintaan semakin banyak pula memproduksi barang. Kenaikan produksi tersebut yang akan menambah penggunaan tenaga kerja. Dengan demikian berhubungan erat dengan tingkat pendapatan nasional yang dicapai dengan penggunaan tenaga kerja yang dilakukan, semakin tinggi pendapatan nasional semakin banyak penggunaan tenaga kerja dalam perekonomian. Serta pengangguran yang ada. (Sukirno, 2006).

Menjadi pengusaha dan membuka lapangan kerja adalah salah satu cara untuk mengurangi pengangguran di Indonesia. Lebih lanjut anjuran kerja atau usaha dalam Islam bagi setiap individu yang ada dimuka bumi ini sangatlah tegas dengan memanfaatkan sumberdaya alam yang ada Karena kerja membawa pada keampunan, sebagaimana sabda Rasulullah Muhammad Saw:
"Barang siapa diwaktu sorenya kelelahan karena kerja tangannya, maka di waktu sore itu ia mendapat ampunan". (HR.Thabrani dan Baihaqi). (Laila, 2012) salah satu contoh bekerja demi mendapatkan keuntungan ialah berbisnis. Juga terdapat ayat Al-Quran dalam surat Al-Taubah (9):105

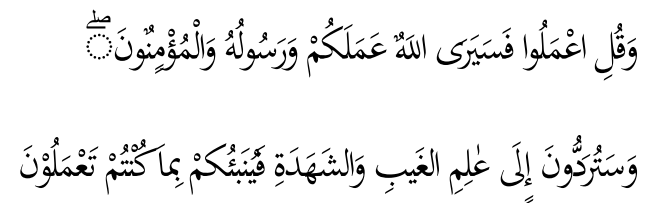

\section{Dan katakanlah (Muhammad): “} Bekerjalahkamu maka Allah dan rosulnya serta orang-orang mukmin akan melihat pekerjaanтu itu, dan kamu akan dikembalikan kepada (Allah) yang mengetahui yang gaib dan yang nyata, lalu diberitakannya kepada kaти apa yangg kamu kerjakan. (QS. At-Taubah $\{9\}$ 105).

Dalam ayat tersebut dapat disimpulkan bahwa Allah pasti melihat atau menyaksikan prestasi manusia dan Allah akan membalas amal perbuatan itu dalam bentuk kekayaan. Demikian pula dengan Rasulullah dan orang-orang beriman lainnya juga turut menyaksikan sehingga mereka memberi hak-hak kepada kita didunia ini. (Suma, 2015)

Dikuatkan kembali dengan hadis nabi “Tidak ada makanan yang dimakan seseorang yang lebih baik dari makanan yang merupakan usaha 
tangannya sendiri dan sesungguhnya nabi Allah Daud makan dari hasil usaha tanganya sendiri. Dalam islam bekerja dibatasi dengan dua hal yakni, keikhlasan dan ibtida' atau mengikuti Rosulullah. Hendaknya tujuannya ialah mencari ridho Allah dan mengikuti sunnah Rasul. (AlMushlih, 2013).

Syauqi Ahmad Dunya (dikutip oleh Idri, 2015 dalam bukunya Tanwil alTanmiyah fi al-Iqtishad al-Islami menyebutkan bahwa bekerja atau usaha dalam rangka membangun ekonomi termasuk kewajiban yang sakral (farduh Muqaddash) keagamaan sifatnya.(Idri, 2015). Islam mewajibkan bekerja dan membangun perekonmian demi keberlangsungan hidup.

Dari hadist dan ayat tersebut Islam mewajibkan setiap muslim, khususnya yang memiliki tanggungan untuk bekerja atau berusaha (mampu dalam segi apapun) Bekerja merupakan salah satu sebab pokok manusia memperoleh harta kekayaan. Untuk memungkinkan manusia berusaha mencari nafkah, Allah Swt melapangkan bumi serta menyediakan berbagai fasilitas yang dapat dimanfaatkan untuk mencari rizki. Karena Tujuan Allah menciptakan manusia dimuka bumi ini ini salah satunya untuk menjadi khalifah yakni pemimpin dibumi.
Ternyata Islam telah lama mengenalkan tentang adanya bisnis bermitra. Ayat tersebut menjelaskan mencari harta atas dasar suka sama suka, maksudnya ialah saling merelakan atas apa yang kerjakan. Sama halnya dengan konsep waralaba didalamnya terikat suatu pejanjian dan kesepakatan antara kedua belah pihak sekaligus transparan dalam melakukan segala macam bentuk franchise dengan menginformasikan apa yang terdapat dalam manajemen usaha yang telah diembannya.

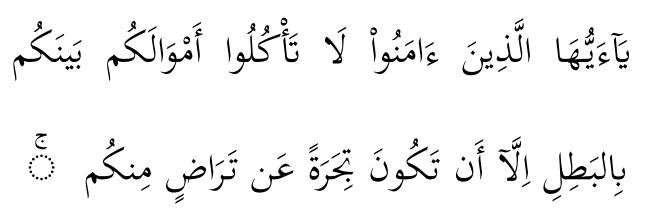

Wahai orang-orang beriman dan janganlah sebagian kamu memakan harta sebagian yang lain diantara kamu dengan cara yang batil kecuali atas dasar suka sama suka diantara kamu.(QS. An-Nisaa' \{4\}: 29)

Nabi Muhammad SAW telah dulu mengajarkan kepada umatnya berbisnis dengan bentuk kerjasama yakni bermitra dengan Khadijah (yang kemudian menjadi istri Nabi). Dengan menjualkan barang dagangan milik Khadijah Nabi Muhammad mendapatkan upah atas apa 
yang telah dilaksanakan. Cukup bermodal kejujuran dan amanah terhadap apa yang telah diperintahkan.

Prinsip Islam tentang kebebesan ekonomi berarti bahwa setiap individu diberi kebebesan oleh Allah dalam hal mencari harta, memilikinya dan menikmatinya. Prinsip ini juga memilki arti kebebasan dalam memilih profesi, bisnis maupun lapangan kerja dalam mencari nafkah. Akan tetapi Islam membedakan terkait halal dan haramnya suatu produksi, distribusi, maupun konsumsi. Hanya halal saja yang dibolehkan. (Chudri 2012)

Dalam kehidupan ekonomi, Islam telah mengakui adanya kebebasan untuk menjalankan kegiatan ekonomi. Yakni segala bentuk perdagangan yang bermunculan dari tahun ketahun. Akan tetapi kebebasan ini tidak bersifat mutlak. Kebebasan yang dibatasi dengan kemashlahatan (kehati-hatian dalam menjaga amanah dalam islam) dan menolak kemudharatan individu dan masyarakat publik. Islam menganjurkan kehati-hatian dalam hal muamalah. (Sinn., 2006). Seperti halnya sebutan dalam kaidah fikh

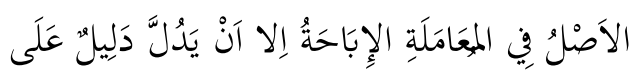<smiles>[AsH2]</smiles>

"pada dasarnya semua bentuk muamalah boleh dilakukan kecuali ada dalil yang mengaharamkannya."

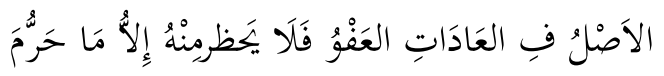

"Hukum asal dalam muamalah adalah pemaafan, tidak ada yang diharamkan kecuali apa yang diharamkan Allah".(Djazuli, 2011).

Perjanjian dalam bisnis waralaba dapat diartikan sebagai akad dalam bisnis Islam, akad memilki arti ikatan atau penghubung antara dua hal, dalam arti istilah akad merupakan keinginan diri untuk mengikat dengan suatu yang lain dan menggunakan cara yang memunculkan adanya komitmen tertentu yang disyariatkan.(Al-Mushlih, 2013).

Dengan akad seseorang akan merasa saling bertanggung jawab terhadap apa yang telah diakad serta kepada siapa ia berakad. dalam lingkup usaha atau bisnis akad termasuk bagian terpenting bagi pelaku bisnis. Dengan perjanjian, pelaku bisnis akan mendapatkan penerangan 
dalam menjalankan bisnis yang ditekuninya. Sebagaimana ayat dibawah ini. Allah memerintah memenuhi akad yang telah disebutkan.

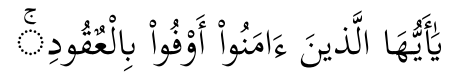

Hai orang-orang yang beriman, penuhilah akad-akad itu. (QS. AlMaidah\{5\}: 1)

Konsep bisnis waralaba pada intinya saling tolong menolong yakni menolong unit usaha kecil menjadi besar Perlu penekanan franchisor menolong dengan memberi bantuan skil dan manajemen bisnis, baik berupa konsep bisnis yang telah dipakainya dan keterampilan untuk dipakai oleh pihak lain (franchisee) dengan cara transparan antar keduanya. Oleh karenanya suatu kewajiban dalam agama islam terkait menolong antar sesama. Sebagaimana ayat Al-Quran dalam surah Al-Maidah ayat menegaskan

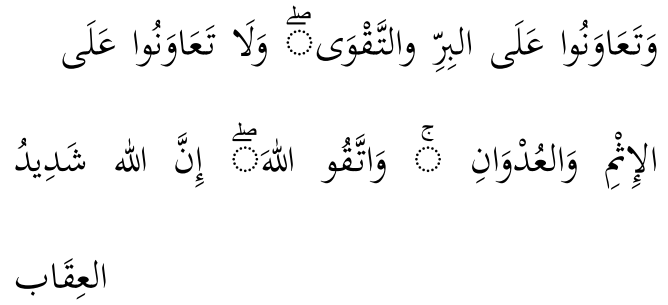

Tolong menolonglah kamu dalam (mengerjakan) kebajikan dan takwa dan jangan tolong menolong kamu dalam berbuat dosa dan pelanggaran dan bertakwalah kamu kepada Allah sesungguhnya siksa Allah lebih berat. (QS. Al-Maidah \{5\} 2).

Tolong menolong dalam Islam telah diajarkan sejak dahulu pada zaman Rasulullah, pada hakikatnya lebih mengedepankan menolong orang lain dalam aspek kebaikan. Terpenting bagi bisnis waralaba telah jelas pengusaha besar menolong pengusaha kecil demi menjadi pengusaha juga dan bisa membuka peluang pekerjaan bagi orang lain. Dengan begini pengangguran semakin terkikis sebab terdapat lapangan pekerjaan.

Eksistensi bisnis waralaba dalam ekonomi Islam lebih mengedepankan prinsip Alquran dan Hadist. Konsep waralaba merupakan suatu bentuk perjanjian timbal balik, karena keduanya berkewajiban untuk memenuhi prestasi tertentu. Dalam waralaba diperlukan adanya prinsip (Transparansi) keterbukaan dan kehati-hatian. Hal ini sangat sesuai dengan rukun dan syarat akad menurut hukum Islam dan larangan transaksi "Gharar" (ketidakjelasan atau keraguan). Dan sesuai dengan azas akad yaitu AshShidq (Kejujuran dan Kebenaran) dan AIKitabah (Tertulis). (Syahrani, 2012)

Dalam hal ini konsep bisnis waralaba (Franchising) tidaklah bertentangan 
dengan ekonomi islam selama tidak ada kejelasan terkait larangan dalam ekonomi islam diantaranya makanan haram daging babi atau anjing, dan minuman haram yakni khamr. Sekaligus transaksi haram yakni, penimbunan harta dengan cara penipuan, atau lain sebagainya.

\section{Bisnis Waralaba dalam konsep dan praktik Perspektif Ekonomi} Islam

Bisnis waralaba hakikatnya telah lama dikenal dalam ekonomi Islam dengan nama syirkah atau musyarakah (kerjasama). Kerjasama dilakukan untuk memperoleh keuntungan sesuai kesepakatan awal atas waktu tertentu (sesuai perjanjian). Prinsip dalam waralaba terdapat keterbukaan (transparansi) dan kehati-hatian yang tertuang dalam prinsip ekonomi islam yaitu gharar (ketidak pastian atau ketidakjelasan) dan tidak diperkenankan mengaplikasikannya terhadap dunia bisnis. (Setiawan, 2013)

Syirkah adalah nama lain dari bermitra dalam ekonomi Islam. Secara bahasa kata syirkah ialah perserikatan dua orang atau lebih. Syirkah bermakna kerjasama antara dua orang atau lebih dalam berbisnis atau terhadap kekayaan. Islam telah menyatakan sah dan legal terhadap berbisnis dengan cara bermitra atau kerjasama. (Chudri, 2012a).

Dalam bahasa arab syirkah berarti percampuran atau interaksi, juga boleh diartikan membagikan sesuatu antara dua orang atua lebih sesuai kebiasaan yang ada. Dalam terminology ilmu fikih dapat diartikan persekutuan usaha untuk mengambil hak atau beroperasi. (AlMushlih, 2013)

Sedangkan menurut Muhammad dalam bukunya Etika Bisnis Islam menyatakan suatu system terkait pembagian hasil usaha antara penyedia dana dan pengelola dana (Muhammad, 2004) didalam hukum, syirkah memilki arti kerja sama (partnership) antara dua orang atu lebih baik dala berbisnis maupun kekayaan. Berbisnis dengan cara kerjasama telah disahkan sekaligus dilegalkan dalam islam. (Chudri 2012)

Terdapat dua pembagian syirkah diantaranya, syirkah tamlik (sebab kepemilikan) dan syirkah uqud (akad dua orang) Sedangkan bisnis waralaba ini termasuk dalam syirkah macam kedua yakni syirkah uqud (transaksi) yaitu dua orang bersekutu dalam modal dan keuntungan. Keduanya sama-sama bermodal, letak perbedaanya ialah Dalam hal ini franchisor dengan bermodalkan ide 
kreatif diantaranya merek dagang, logo, manajemen usaha dan tenaga bekerja seperti pelatihan usaha yang akan diberikan kepada franchisee. Begitu pula dengan franchise cukup bermodal dana terhadap apa yang akan diwaralabakan tersebut. Keduanya saling ikut serta terhadap bisnis waralaba yang akan dijalankan sesuai perjanjian yang telah ditetapkan.

Rukun dalam syirkah ialah ijab dan qobul menurut ulama hanifiyah. Bisa disebut sebagai akad yang menentukan adanya syirkah. Sedangkan persyaratan yang harus ada dalam syirkah ialah merdeka (Dalam islam merdeka ialah memiliki hak bebas atas setiap sesuatu, tidak terikat dengan tuannya atau majikannya.

Merdeka berarti bebas dalam melakukan sesuatu), baligh (Cukup umur, dewasa, mengetahui mana yang hak dan mana yang batil. Serta matang dalam hal berpikir), dan pintar (Dalam KBBI diartikan sebagai pandai atau cakap. Mahir dalam melakukan atau mengerjakan sesuatu) menurut malikiyah. (Maratun Shalihah, 2016). Malikiyah menyebutkan syarat tersebut supaya tidak terdapat kekeliruan dalam bermitra. Terdapat penjelasan dalam buku karangan Shalah
ash-Shawi dan Abdullah al-Mushlih membagi empat atas syirkah uqud menurut mayoritas ulama;

a. Syarikah al-Inan, yaitu bersekutu dalam modal, usaha dan keuntungan. Maksudnya ialah kerjasama antara dua orang atau lebih dengan mengumpulkan modal yang dimiliki untuk membuka usaha lalu membagi keuntungan bersama sesuai kesepakatan.

b. Syarikah al-Abdan, yakni syarikah usaha. Lebih jelasnya adalah bekerjasama dalam tubuh atau fisik seperti halnya kerjasama antara dokter di klinik.

c. Syarikah al-Wujuh, bekerjasama dengan menggunakan nama baik yang dimiliki oleh pihak pekerjasama dan keuntungan mereka bagi dengan kesepakatan.

d. Syarikah al-Mufawwadah, ialah bekerjasama dalam penjaminan dan hak-hak yang serasi dengan modal, usaha dan hutang. Dimana masingmasing pihak memilki usaha, modal dan hutang-piutang yang sama. 
Terdapat beberapa rukun dalam syirkah inan yang kesemua rukun berkaitan erat dengan bisnsi sistem waralaba ini. Diantaranya, Pelaku (dua transaktor), dan keduanya harus memiliki kelayakan dalam berbisnis dan objek transaksi yang meliputi modal (harus diketahui, jelas) usaha (masing-masing pihak bebas dalam mengelola usahanya), dan yang terahir yakni keuntungan (harus diketahui jumlahnya oleh masing-masing pihak). (Al-Mushlih, 2013). keuntungan dalam bisnis ini yakni bagi hasil terhadap apa yang telah diperoleh.

Inti dari penjelasan di atas ialah syirkah dalam waralaba selain berbentuk perserikatan berbagai modal dari pemberi waralaba dan penerima waralaba pihak yang bermitra berhak ikut terlibat dalam manajemen usaha, para pihak dapat membagi pekerjaan mengelola usaha sesuai kesepakatan. Hal ini terdapat dalam konsep perjanjian waralaba yang telah dipaparkan sebelumnya.

\section{SIMPULAN}

Dari beberapa uraian di atas dapat ditarik kesimpulan sebagaimana berikut, Islam membolehkan atau menghalalkan segala macam bentuk muamalah kecuali terdapat dalil yang menjelaskan keharamanya. Bisnis waralaba adalah bisnis yang merupakan kerjasama antara pihak lemah (franchisee) dengan pihak kuat (franchisor), dimana keduanya dapat melihat kejelasan terkait apa yang harus dilakukakannya dalam bisnis sistem waralaba ini. Karena didalamnya terdapat sebuah perjanjian atau akad yakni sebuah ikatan yang membuat pelaku bertanggung jawab terhadap apa yang telah disepakati dalam akad.

Dengan semakin pesatnya teknologi, serta pemikiran yang serba langsung, konsep waralaba adalah kuncinya. Terbukti keberadaanya telah menjadi peluang bisnis terbanyak di Indonesia saat ini. Berikut usaha pemakai konsep waralaba di Indonesia antara lain, Es Teler 77, Bakso Cak Eko, Indomart, dan Alfamart. Termasuk 212 Mart yang merupakan salah satu konsep waralaba syariah.

Islam telah dahulu mengenalkan syirkah (kerja sama) dalam berbisnis supaya lebih mudah dalam meraup untung. Didapat dua kali keuntungan dengan bermitra yakni keuntungan finansial dan keuntungan mempererat tali persaudaraan umat muslim khususnya di Indonesia ini.

Sistem waralaba termasuk dalam syirkah uqud, yakni kerjasama akad (Perjanjian). Didalamnya terdapat 
beberapa kesaksian dan ikatan antar pelaku waralaba.

\section{DAFTAR PUSTAKA}

Al-Mushlih, S. A.-S. dan A. (2013). Fikih ekonomi Islam. Jakarta: Darul-Haq.

Chudri, M. syarif. (2012a). Sistem ekonomi Islam. Jakarta: Kencana.

Chudri, M. syarif. (2012b). Sistem Ekonomi Islam. Jakarta: Kencana.

Darmawan, W. (2008). Analisis Sistem Penetapan Franchise Fee Dan Royalty Fee Pada Franchise BRC.

Djazuli, A. (2011). Kaidah-kaidah Fikih (pertama). jakarta: kencana.

Ghufron, M. I. (2017). Konsep Mashlahah Maximizer Pada Hotel Syariah Perspektif Etika Bisnis Islam, 1(2), 131-143.

Idri. (2015). Hadis Ekonomi Ekonomi dalam Perspektif Hadis Nabi (pertama). Jakarta: Kencana.

Laila, N. (2012). Pengantar ekonomi islam. malang: Kumi Advertising.

Linda, R. (2015). Ekonomi Islam Teori dan aplikasinya. PT. RadjaGrafindo Persada (Vol. 1).

Malik, C. (2007). Implikasi Hukum
Adanya Globalisasi Bisnis Franchise. Hukum, 14(1), 97-113.

Maratun Shalihah. (2016). Konsep Syirkah Dalam Waralaba. Jurnal Tahkim (Vol. XII).

Mayasari, R. E. (2017). 247 waralaba (franchise) dalam sistem hukum islam dan hukum positif di indonesia, 19(2), 247-254.

Muhammad. (2004). Etika Bisnis Islam. Yogyakarta: akademi Manajemen Perusahaan YKPN.

Puji Sulistyaningsih. (2017). Sistem Bagi Hasil dalam Perjanjian Waralaba (Franchise) perspektif hukum Islam, 8(1), 139.

Rivai, M. M. (2012). Pengaturan Waralaba di Indonesia: Perspektif Hukum Bisnis. Liquidity, 1(2), 159-166.

Rusli, T. (2015). Analisis terhadap perjanjian waralaba (, 6(26).

Setiawan, D. (2013). Kerja Sama (Syirkah) Dalam Ekonomi Islam. Ekonomi, 21(September), 1-8.

Sinn., D. A. I. A. (2006). Manajemen sayriah sebuah kajian historis dan kontemporer. Jakarta: PT. RajdaGrafindo Persada. 
Sukirno, Sa. (2006). Makro Ekonomi

131-145.

Pengantar bisnis edisi ketiga.

Suma, M. A. (2015). tafsir ayat ekonomi

teks terjemah dan tafsir. jakarta:

Amzah.

Syahrani, H. (2012). Bisnis Waralaba Di

Indonesia Dalam Perspektif Hukum

Bisnis Syariah. At-Taradhi, 3(2), 